\title{
Zoogeographic Evidence for Late Tertiary Lateral Slip \\ On the San Andreas Fault California
}

GEOLOGIGAL SURVEY PROFESSIONAL PAPER 593-D 

Zoogeographic Evidence for Late Tertiary Lateral Slip

On the San Andreas Fault California

$B y$ W. O. ADDICOTT

C O N T R I B U TIO N S TO PALE O N T O L O G Y

GEOLOGICAL SURVEY PROFESIONAL PAPER 593-D

Large post-early Miocene right lateral

movement is suggested by early Miocene faunal distributions and paleogeography

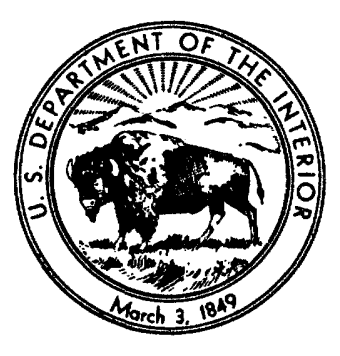

UNITED STATES GOVERNMENT PRINTING OFFICE, WASHINGTON : 1967 


\section{UNITED STATES DEPARTMENT OF THE INTERIOR \\ STEWART L. UDALL, Secretary \\ GEOLOGIGAL SURVEY \\ William T. Pecora, Director}

For sale by the Superintendent of Documents, U.S. Government Printing Office

Washington, D.C. 20402 - Price 20 cents (paper cover) 


\section{CONTENTS}
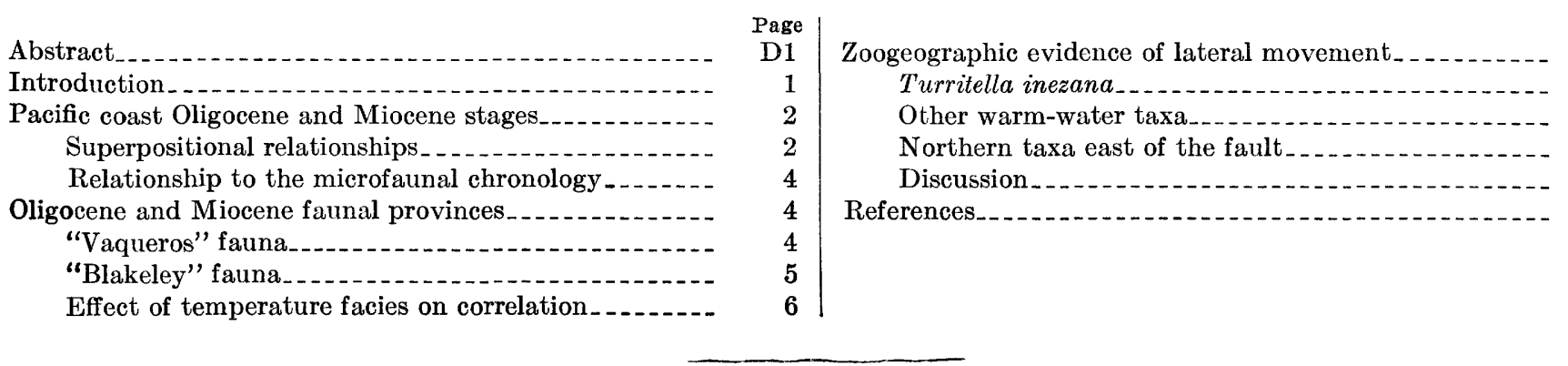

Page
D6
6
7
7
9
10

\section{ILLUSTRATIONS}

FIgure 1. Traditional sequence and correlation of Oligocene and Miocene megafaunal and microfaunal provincial stages

2. Relationship of middle Tertiary Acila biozones of Schenck (1936) to Pacific coast megafaunal "stages", . .

3. Proposed correlation and succession of Oligocene and Miocene Pacific coast mega-

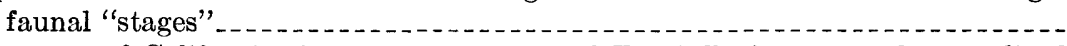

4. Index map of California showing occurrenees of Turritella inezana and generalized paleogeography during the "Vaqueros" and "Blakeley Stages"..............

Page

D3

3

7

8 


\title{
CONTRIBUTIONS TO PALEONTOLOGY
}

\section{ZOOGEOGRAPHIG EVIDENGE FOR LATE TERTIARY LATERAL SLIP ON THE SAN ANDREAS FAULT, GALIFORNIA}

\author{
By W. O. Addicott
}

\begin{abstract}
The distributional pattern of the index species for the "Vaqueros Stage" of the Pacific coast provincial time-stratigraphic classification, Turritella inezana Conrad, is in agreement with earlier postulates of large post-early Miocene right lateral slip on the San Andreas fault. Inferred distribution of early Miocene seaways and embayments, though somewhat speculative, strengthens the thesis of large laterial dislocation. Reexamination of the biostratigraphic basis of Pacific coast midTertiary megafaunal correlation indicates that the "Blakeley Stage" of Washington and the "Vaqueros Stage" of California are at least in part coeval.
\end{abstract}

\section{INTRODUCTION}

In attempting to trace distributional patterns of certain warm-water elements of the "Vaqueros" fauna and the related identification of early Miocene shorelines and basins of marine deposition, a distinct north ward change from warm- to temperate-water molluscan assemblages became apparent. (Quotation marks are used herein to distinguish the Pacific coast provincial stages of Weaver and others (1944) from formations bearing the same name. The "Vaqueros Stage" is based on the warm-water molluscan fauna of the Vaqueros Formation monographed by Loel and Corey (1932). Megafaunal workers generally regard it as the principal lower Miocene timestratigraphic unit in California and Baja California.) The pattern is anomalous in that east of the San Andreas fault the change takes place in the Diablo Range of central California, whereas west of the fault there is no such change as far north as the "Vaqueros" fauna can be recognized onshore-southern Mendocino County. In comparing early Miocene zoogeographic data on either side of the San Andreas fault, the distribution of the gastropod genus Turritella seemed to be of particular importance because of its abundance and widespread distribution. Moreover, the taxonomy and stratigraphic occurrence of this genus have received a thorough, modern treatment by Merriam (1941).

In central and northern California, the warm-water
"Vaqueros" index species Turritella inezana Conrad, a member of the subgenus Torcula (Turritella altiliva stock of Merriam, 1941), has a noncontiguous distributional pattern across the San Andreas fault which may be the result of large post-early Miocene right-lateral slip. The inferred movement is of comparable magnitude to that suggested by the regional stratigraphic analysis of Hill and Dibblee (1953). Other warm-water "Vaqueros" taxa generally support the interpretation of large lateral slip as do certain early to middle Miocene mollusks of temperate aspect that have diametrically opposed distributional patterns. The zoogeography of $T$. inezana and some other elements of the "Vaqueros" fauna, related paleogeography, and late Oligocene and early Miocene faunal correlations form the basis of this report.

A principal obstacle to zoogeographic analysis of the middle Tertiary gastropod Turritella inezana and other elements of the associated molluscan fauna is correlation. The problem is twofold, involving the need for: (1) redefinition, refinement, and renaming (Am. Comm. Strat. Nomenclature, 1961, art. 32c, d) of the so-called megainvertebrate stages of Weaver and others (1944, p. 572) ; and (2) development of more precise long-range interbasinal correlation.

Solution of the first problem is largely a matter of continued careful and detailed stratigraphic collecting and mapping designed to develop biostratigraphic standards adequate for the formal designation of stages and zones. Limitations imposed by inadequate standards for correlation severely handicap analysis of faunal distributions and the use of these in deciphering geologic history. With some qualifications, however, available chronostratigraphic control provides an adequate framework for the following analysis of late Oligocene to early Miocene zoogeographic data.

The second problem is a matter of correlation between different mollusean provinces. Miocene interbasinal faunal correlation along the Pacific coast based upon 
shallow-water marine mollusks has proved to be quite effective within a given molluscan province. However, correlation between adjoining faunal provinces is often extremely difficult. Of particular concern to the following discussion is the warm-water molluscan fauna of the "Vaqueros Stage," which has provided an excellent standard for correlation in Baja California and the California Coast Ranges. This distinctive faunal unit cannot be traced northward from California although the unbroken Oligocene and Miocene depositional sequence in some of the Oregon and Washington marine basins must necessarily include contemporaneous faunal assemblages. Because the "Vaqueros Stage" is predicated largely on species with geographic ranges restricted to an early Miocene warm-water faunal province, correlation with faunas of temperate provinces is difficult. This situation has led to a considerable overlap of the Pacific northwest "Blakeley Stage" and the California "Vaqueros Stage." Selection of species with wide geographic range zones and narrow biozones to characterize chronostratigraphic units and application of the principles of modern faunal differentiation to fossil faunas may help to solve this problem.

\section{PACIFIC COAST OLIGOCENE AND MIOCENE STAGES}

Reexamination of certain biostratigraphic data upon which the Pacific coast Oligocene and Miocene megafaunal sequence is based is prerequisite to the subsequent discussion of "Vaqueros" marine paleogeography and faunal distribution. Faunal and stratigraphic relationships reviewed herein lead to the conclusion that the "Vaqueros Stage" of the California chronology is at least in part equivalent to the "Blakeley Stage" of Washington and Oregon.

Although the basic sequence of Pacific coast megainvertebrate faunas is reasonably well worked out, it is not controlled by biostratigraphic data adequate to permit formal designation of stages. Because type sections and demonstrable superpositional relationships to adjacent time-stratigraphic units are lacking, the megafaunal stages herein used are enclosed in quotation marks. These deficiencies have not posed a serious obstacle to their present rather gross usage, but they have prevented refinements in the megafaunal sequence comparable to the relatively well-documented Miocene microfossil standards of Kleinpell (1938).

Following the long-established treatment (Weaver and others, 1944; Durham, 1954) of the "Vaqueros Stage" and the upper part of the underlying "Blakeley Stage" as provincial equivalents of the European Miocene Series (fig. 1, present report), these units are herein referred to the Miocene. Foraminiferal specialists are divided as to the position of the Oligocene-
Miocene boundary in their provincial sequence. Kleinpell and Weaver (1963) place it within the Saucesian Stage; Bandy and Kolpack (1963) draw it near the middle of the Zemorrian Stage. Lipps (1965) has identified planktonic foraminifera from the upper part of the Zemorrian Stage in southern California that are correlated with the Oligocene Globigerina oligocaenica zone of East Africa (Eames and others, 1962).

Mollusean paleontologists seem to have generally followed Durham $(1944 ; 1950 ; 1954)$ in treating the "Blakeley Stage," a unit primarily confined to Oregon and Washington, and the exclusively Californian "Vaqueros Stage" as successive time-stratigraphic units in the provincial chronology (fig. 1) although this relationship has not been convincingly demonstrated by superpositional criteria. This lack of documentation apparently has not recived critical investigation despite the implied lumping of these units by Kleinpell (1938, fig. 14). Clark (1943, p. 188), however, subsequently expressed doubt that the "Blakeley" and "Vaqueros" are equivalent.

\section{SUPERPOSITIONAL RELATIONSHIPS}

Mollusks characteristic of the "Vaqueros Stage" have not been reported from Washington. A small molluscan assemblage from the Molalla quadrangle near Portland, Oreg., once considered a northern extension of the "Vaqueros" fauna of central and southern California (Durham and others, 1942) seems to be referable to the "Blakeley Stage" on the basis of subsequent collections studied by Vokes (in Peck and others, 1964, p. 26). Other than the occurrence of Turritella inezana forma hoffmanni and Chlamys cf. C. hertleini near Point Arena, Calif. (Addicott, 1967), "Vaqueros" assemblages are not known north of the Santa Cruz Mountains in central California (lat $37.4^{\circ} \mathrm{N}$.).

Conversely, faunal assemblages referable to the "Blakeley Stage" are principally from Washington, Oregon, and farther north. The only assemblages from California clearly referable to the "Blakeley Stage" are from the San Ramon Sandstone and Kirker Tuff (Clark, 1918; Weaver, 1949) of Contra Costa and Napa Counties (lat $38^{\circ} \mathrm{N}$.). This fauna includes such Blakeley species as Aforia clallamensis, Liracassis apta, Turritella diversitineata, and Acila gettysburgensis (Clark, 1918; Durham, 1944; Durham in Ham, 1952) and is correlated with the Echinophoria apta zone by Durham (1944) and Primmer (1964). Although the Pleito Formation of Wagner and Schilling (1923) of the San Emigdio Mountains at the south end of the San Joaquin Valley contains some species that also occur in the San Ramon Sandstone (Wagner and Schilling, 1923, p. 252; Alex Clark in Schenck, 1936, p. 75), assignment to the 


\begin{tabular}{|c|c|c|c|}
\hline 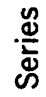 & $\begin{array}{c}\text { Megafaunal } \\
\text { "stages" }\end{array}$ & $\begin{array}{c}\text { Microfaunal } \\
\text { stages }\end{array}$ & $\frac{\mathscr{E}}{\mathscr{L}}$ \\
\hline \multirow{3}{*}{ 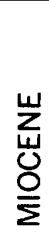 } & \multirow{2}{*}{ Temblor } & Luisian & \\
\hline & & Relizian & 岂 \\
\hline & Vaqueros & & $\bar{\Sigma}$ \\
\hline \multirow{2}{*}{ 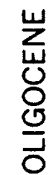 } & Blakeley & Zemorrian & \\
\hline & Lincoln & Refugian & 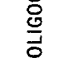 \\
\hline
\end{tabular}

Figure 1.-Traditional sequence and correlation of Oligocene and Miocene megafaunal and microfaunal provincial stages (after Durham and others, in Durham, 1954, fig. 3). One conclusion of the present report is that the "Vaqueros" and "Blakeley" are in part time-equivalent (fig. .3). Moreover, Corey (1954) indicates that in southern California the lower part of the Saucesian Stage is equivalent to the "Vaqueros Stage," a conclusion reached by J. G. Vedder (oral commun., 1963) the basis of biostratigraphic studies in the Caliente Range.

"Blakeley Stage" does not seem warranted. Rather the presence of Acila shumardi (Dall) at many of Wagner and Schilling's localities in the lowest and uppermost "zones" of their Pleito Formation (1923, p. 245-246, 252 ; Schenck, 1936) indicates reference to the Oligocene "Lincoln Stage," the limits of which are coextensive with the biozone of this species (fig. 2). These faunal assemblages are overlain by assemblages including Lyropecten magnolia and other species referable to the "Vaqueros Stage" (Loel and Corey, 1932). The San Ramon seems to be referable to the biozone of Acila gettysburgensis (Reagan) based on the occurrence of that species listed by Clark (1918). This biozone is younger than the biozone of $A$. shumardi (Schenck, 1936, p. 44; fig. 2, present report). The earliest occurrence of A. gettysburgensis is in strata referable to the "Blakeley Stage," the latest in strata referable to the middle Miocene "Temblor Stage."

Faunal assemblages assignable to the "Vaqueros Stage" are overlain conformably by strata containing mollusk associations characteristic of the "Temblor Stage" in the southeastern Caliente Range (Repenning and Vedder, 1961), Kern River area (Addicott, 1965), in the northern part of the Temblor Range, and in many other areas in central and southern California. Recent mapping in the northern Olympic Peninsula of Washington (Brown and Gower, 1958; Gower, 1960) indi-

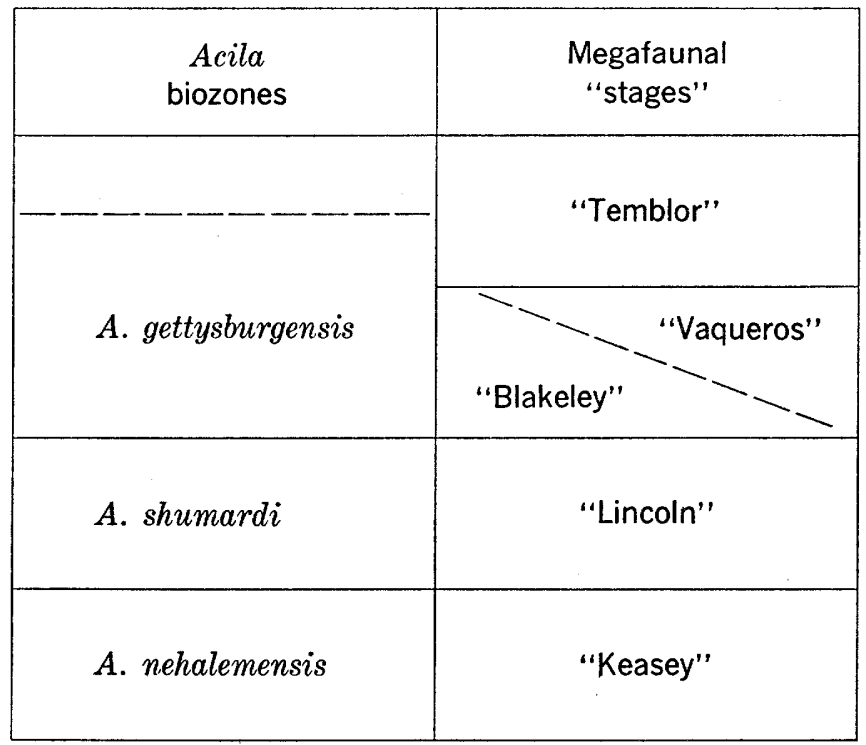

FIgURE 2.-Relationship of middle Tertiary Acila biozones of Schenck (1936) to Pacific coast megafaunal "stages."

cates that there is a gradational contact between the upper part of the Twin River Formation and the overlying Clallam Formation rather than an unconformity as previously thought (Weaver and others, 1944, p. 595596). Therefore, there seems to be no hiatus separating the assemblages of the type Echinophoria apta zone in the upper part of the Twin River Formation, the standard for the upper part of the "Blakeley Stage," from molluscan assemblages of the overlying Clallam Formation which have long been correlated with the California middle Miocene ("Temblor Stage") (Arnold and Hannibal, 1913; Durham, 1944; Weaver and others, 1944) and with the Astoria Formation of Oregon and southwestern Washington (Arnold, 1906 ; Etherington, 1931; Weaver, 1937; Moore, 1963).

In Contra Costa and Napa Counties, Calif., "Blakeley" assemblages of the San Ramon Sandstone are overlain by "Temblor Stage" faunal assemblages in the lower part of the Monterey Shale and Monterey Group (Weaver, 1949). The physical relationship between these units in Contra Costa County is disconformable (Lutz, 1951, p. 376) but possibly conformable in the Napa County exposures to the north (Weaver, 1949, p. 74). Although there are very few "Vaqueros" species in the Napa County exposures of the San Ramon Sandstone, there are many restricted "Temblor" taxa in the overlying basal Monterey Shale: Lirophora latilaminosa (Anderson and Martin), Aequipecten andersoni (Arnold), Nuculana temblorensis (Anderson and Martin), Cancellaria nevadensis Anderson and Martin, Ophiodermella temblorensis (Anderson and Martin), Nassarius arnoldi (Anderson), Megasurcula keepi (Ar. 
nold), and Tegula dalli (Arnold). In Contra Costa County the hiatus separating the San Ramon and the Kirker Formation of Pease (1954) from the overlying Sobrante Sandstone of the middle Miocene Monterey Group may be a local feature representing no more than a brief gap in deposition in view of Pease's (1954, p. 19) conclusion that "The lithologic transition from Kirker tuffaceous sandstone to Sobrante sandstone [on Sobrante anticline] is gradational, and there is no noticeable divergence of attitude between the two units."

To summarize, "Vaqueros" molluscan assemblages are restricted to California, whereas "Blakeley" assemblages occur in northern California, Oregon, and Washington. Nowhere have assemblages referable to these chronostratigraphic units been found in superpositional sequence. Moreover, mollusks referable to the middle Miocene "Temblor Stage" conformably overly the type section of the "Blakely Stage" in Washington and many sections referable to the "Vaqueros Stage" in California. Rocks referable to the "Blakeley Stage" overly strata included in the Oligocene Acila shumardi biozone (= "Lincoln Stage") in Washington as do strata referable to the "Vaqueros Stage" in the southern part of the San Joaquin Valley, Calif.

\section{RELATIONSHIP TO THE MICROFAUNAL CHRONOLOGY}

Evidence from benthonic foraminifera that occur in strata containing "Blakeley" and "Vaqueros" megafossils offers an additional means of evaluating relationships between these units. Kleinpell (1938) records microfossils of the lower part of his Zemorrian Stage from the San Ramon and Gallaway Formations of northern California and the Blakeley Formation of Washington. Because Turritella inezana forma hoffmanni occurs stratigraphically below the lower Zemorrian foraminiferal assemblages of the Gallaway Formation of Weaver (1944; Addicott, 1967), it is clear that the biozone of Turritella inezana includes strata that have been classified as lower Zemorrian (Kleinpell, 1938).

Although Kleinpell (1938, fig. 14) showed the biozone of Turritella inezana extending to the base of his Zemorrian microfaunal stage, the lowest indicated occurrence with foraminiferal assemblages was in the upper part of the Zemorrian Stage. In the central California Coast Ranges a few miles northeast of Santa Maria, lower Zemorrian microfossils occur stratigraphically above an assemblage including such "Vaqueros" molluscan guides as Lyropecten magnolia and Ostrea vaquerosensis (Kleinpell, 1938, p. 73, fig. 14; Loel and Corey, 1932, p. 102-103). Inasmuch as the lower part of the type sec- tion of the "Blakeley Stage" also seems to be of early Zemorrian age (Kleinpell, 1938), the biozone may correspond to much, if not all, of the "Blakeley Stage."

\section{OLIGOCENE AND MIOCENE FAUNAL PROVINCES}

If the "Blakeley" and "Vaqueros Stages" are in part age-equivalents, the question arises, "Why is conclusive faunal evidence of contemporaneity lacking?" It is the thesis of this report that molluscan faunas characteristic of "Blakeley" and "Vaqueros Stages" represent distinctly different faunal provinces under latitudinal climatic control; as such a very small percentage of species in common would be expected. (A faunal province consists of an assemblage of species of relatively uniform composition. Changes in faunal composition are gradual within a given province along the Pacific coast, whereas the provincial boundaries are marked by very rapid change; Newell, 1948. Moreover, the index species of each "stage" are forms that appear to have had limited geographic as well as temporal ranges. The inferred climatic control of the "Blakeley" and "Vaqueros" faunas is analogous to the modern northward gradient of decreasing marine surface-water temperatures that is primarily responsible for the differentiation of shallowwater modern molluscan provinces along the Pacific coast. Faunal evidence of a northward decrease in shallow-water marine temperature during the latter part of the Tertiary has long been recognized by invertebrate paleontologists (Smith, 1919; Durham, 1950). The effect of the Pacific coast temperature gradient upon longrange faunal correlation, however, is not fully understood or appreciated, although Hall (1960) and Valentine (1961) have recognized late Miocene and late Pleistocene molluscan provinces in California and have stressed the basic climatic control of these former distributional patterns.

\section{"VAQUEROS" FAUNA}

The fauna of the "Vaqueros Stage" is subtropical to tropical in aspect. Many "Vaqueros" species are represented by modern analogs living in the Panamic molluscan province-from the Gulf of California southward to Panama-the shallow-water marine climate of which is characterized as tropical. Some of the "Vaqueros" genera and subgenera that are today restricted to shallow-water tropical and subtropical molJuscan provinces are: Pinna, Spondylus, Lyropecten. Miltha, Dosinia, Chionopsis, Nerita, Turritella (tropical stocks), Architectonica, Oliva, Euclia, Antillophos, Strioterebrum, and Xenophora. Most of the index species that characterize the "Vaqueros Stage" are included in these genera. 


\section{"BLAKELEY" FAUNA}

In contrast to the Vaqueros fauna the somewhat smaller molluscan fauna of the "Blakeley Stage" from northwestern Washington and southern Vancouver Island, British Columbia (Clark and Arnold, 1923; Tegland, 1933; Durham, 1944) is much cooler in aspect-temperate to warm temperate. With few exceptions the "Blakeley" molluscan genera that are still living in the northeastern Pacific Ocean have modern geographic ranges that overlap in the northern part of the Californian molduscan province and the southern part of the Oregonian province. The boundary between these Recent provinces is drawn at Point Conception (lat $34.5^{\circ} \mathrm{N}$.). Fifteen out of 81 genera for which range data are available are limited today primarily to the Oregonian molluscan province. The end points of the southern range of these genera are in the northernmost part of the Californian province or in the Oregonian province. Genera and subgenera suggesting temperate marine conditions on the basis of their modern distribution in the nearshore northeastern Pacific Ocean are: Acila, Limopsis, Nemocardium (Keence), Platyodon, Pitar (Katherinella), Saxidomus, Cyclocardia, Aforia, Amauropsis, Ancistrolepis, Antiplanes, Fusitriton, Irenosyrinx, Searlesia, and "Turcicula." Additional genera that are either extinct or no longer inhabit the nearshore northeastern Pacific Ocean have northwardranging distributional patterns that support the inferred temperate marine hydroclimate. These include Liracassis, Psephaea, Pseudocardium, and Priscofusus.

With the exception of two gastropod taxa, Ficus and Turricula, genera and subgenera characteristic of warm-water molluscan provinces of the eastern Pacific Ocean are not represented in the "Blakeley" fauna.

The temperate aspect of the "Blakeley" fauna is not a new interpretation. Clark and Arnold (1923) maintained that mollusks of the shallow-water Sooke Formation were of a temperate aspect on the basis of about half of the fauna having modem analogs in the Puget Sound area. Kleinpell (1938, p. 158) suggested that the San Ramon fauna, the California equivalent of the "Blakeley Stage," and the Acila gettysburgensis zone "were of a cooler (or deeper) water aspect than the 'Vaqueros' fauna ('Turritella inezana zone')." Bentson $(1940$, p. 200$)$ observed that the late Oligocene faunas of the Pacific coast were of a still cooler aspect than the early Oligocene faunas which she characterized as warm temperate.

Contrasting views were advanced by Durham (1942; $1950)$ and Tegland (1933). Durham (1942, p. 88-89) held that the occurrence of the coral Eusmitia and Siderastrea in the Blakeley Formation, the upper part of the Twin River Formation, and the Sooke Formation indicated that a subtropical marine environment occurred as far north as the Puget Sound area during the "Blakeley" (Echinophoria rex and E. apta zones of Durham, 1944). Subsequently, Durham (1950) interpreted the marine climate to have a minimum average surface-water temperature of not less than $18.5^{\circ} \mathrm{C}$ and thereby suggested a marine environment comparable to that occurring off the Pacific coast of southwestern Baja California today. Modern molluscan assemblages of this area are considered to be subtropical or outer tropical (Hall, 1964). Tegland (1933, p. 102) concluded, without amplification, that aside from Solemya "and a few other deep- or cold-water genera, the fauna of the type Blakeley [Formation=Echinophoria rex zone] has a tropical or subtropical aspect." (Solemya has subsequently been recorded from a temperate shallow-water environment, 6-8 fathoms, off the southern California Coast (Bandy, 1958; Jones, 1964).)

These interpretations are contrary to the zoogeographic evidence of the rather large "Blakeley" molluscan fauna. Surely the mollusks cannot be interpreted as subtropical because there is no distinctive warm-water element. A possible argument to the effect that the "Blakeley Stage" mollusks of northwestern Washington represent moderate-depth associations that might not accurately reflect a presumed warm shallow-water climate can be negated by examination of the temperate assemblages from the coeval, very shallow water Sooke Formation of nearby Vancouver Island. In view of the strong molluscan evidence for a temperate shallow-water marine climate, the significance of the two genera of reef corals Eusmilia and Siderastrea can be questioned. In attributing a "minimum temperature endurable by a vigorous growth of reef corals" of $18.5^{\circ} \mathrm{C}$, Vaughan and Wells (1943. p. 55) indicate that a few hardy forms, including a species of Siderastrea, can endure substantially lower temperatures for a short period of time. Subsequently, Wells (1957, p. 609) states that significant reefs do not occur where temperatures fall below about $18^{\circ} \mathrm{C}$, although a few reef corals can live in temperatures considerably below this. It is suggested that the "Blakeley" corals may have been acclimated to a cooler environment than the $18^{\circ}-18.5^{\circ}$ minimum for vigorous growth cited by Vaughan and Wells. There is also some question as to the meaning of the term "vigorous growth." If it means construction of reeflike masses of coral or a diversity of genera and species, the isolated nature of the few "Blakeley" records (three species from a total of five localities) suggests that these were hardy taxa lying outside of the tropical worldwide belt of vigorous coral growth. 


\section{EFFECT OF TEMPERATURE FACIES ON CORRELATION}

Problems in correlating the Oligocene and Miocene molluscan faunas of California and northwestern Washington may therefore be explained by diverse shallow-water climatic facies. Thus a warm-water index species of the "Vaqueros Stage" such as Turritella inezana and its congeners would not be expected to occur in the cooler water fauna of the "Blakeley Stage." Turritellas do occur in the "Blakeley" fauna and in the overlying Astoria fauna, but they belong to an Oligocene to middle Miocene lineage [T. porterensis-T. oregonensis (Merriam, 1941, p. 43)] that was in part temporally coexistent with the biozone of $T$. inezana yet was generally restricted to cooler water assemblages in more northern latitudes. Nowhere have species of these two lineages been found together. A modern analogy might be the comparison of a Recent assemblage from the Panamic molluscan province of the Gulf of California, or farther south, with a recent temperate assemblage from the central California coast. The latitudinal temperature gradient between these areas is such that there are very few species in common. Shallowwater tropical and subtropical taxa are more affected by this gradient than cool-water species, some of which can extend their range southward by inhabiting progressively deeper, and therefore cooler, waters.

If a chronostratigraphic unit such as the "Vaqueros Stage" is predicated on shallow inner sublittoral tropical and subtropical species, it is clearly difficult, if not impossible, to recognize coeval faunal assemblages of temperate regions. (The problem of distinguishing biogeographic units from time-stratigraphic units is discussed by Valentine (1963), together with appropriate nomenclature for the former.) Bathyal foraminifera may be less affected by the latitudinal temperature gradient than the shallow-water inner sublittoral mollusks. It is important, however, to work with comparable depth assemblages because of the problem of recurring foraminiferal facies. In the Pliocene of the Ventura basin of southern California, for example, progressive shoaling produced a succession of temperature-controlled foraminiferal associations that have an apparent time significance but which are in fact composed of species still living in well-defined depth zones off the coast of southern California (Crouch 1952). Possible effects of bathymetric or temperature facies on Oligocene and Miocene foraminiferal correlation do not seem to have been studied in comparable detail. Beck's (1952) "Pseudo Saucesian Facies," a relatively deepwater Saucesian faunal element that persisted upward into the Relizian and Luisian Stages in central
California, suggests that bathymetric control of some foraminiferal assemblages was operative during the middle Miocene. Rothwell's position (1965) that the "lower Zemorrian" is in need of redefinition because of "misinterpretation of faunas due to biofacies differences and to limited stratigraphic evidence from too few samples" indicates that late Oligocene to early Miocene microfaunal correlation may also have been affected by bathymetric or temperature facies. In this regard, Kleinpell and Weaver stated $(1963$, p. 37) that in some parts of central California a deepwater facies of the Zemorrian may have persisted into Saucesian time.

In summary, available stratigraphic and faunal data suggest that the "Vaqueros" and "Blakeley Stages" are, at least in part, of the same age (fig. 3). This tentative interpretation needs further evaluation by biostratigraphic studies of: (1) an as yet to be designated type section of the "Vaqueros Stage," (2) the San Ramon and Pleito Formations and overlying marine Miocene units, and (3) the Clallam Formation. Although earlier studies of these units (Arnold and Hannibal, 1913; Weaver, 1916; Clark, 1918; Wagner and Schilling, 1923; Loel and Corey, 1932) were excellent efforts at the time, they do not provide sufficiently detailed biostratigraphic data for the definition of megafossil stages, and much of the taxonomic work is in need of revision. Because of the difference in temperature facies between the "Blakeley" and "Vaqueros Stages," it seems doubtful that a single useful chronostratigraphic unit for this segment of the Tertiary can be satisfactorily devised. Future efforts should probably be directed toward the development of separate middle Tertiary sequences for California and northwestern Oregon and Washington.

\section{ZOOGEOGRAPHIC EVIDENCE OF LATERAL MOVEMENT TURRITELLA INEZANA}

The distribution of Turritella inezana, its various subspecies and named variants, has an unusual pattern; occurrences in the outer California Coast Ranges west of the San Andreas fault extend far north of those on the east side of the fault (fig. 4). The northernmost occurrence of this species west of the fault is in the Skooner Gulch Formation of early Miocene age near Point A rena, Mendocino County (lat. $38.9^{\circ}$ N.; Addicott, 1967). Farther south it is known from several localities in the Santa Cruz Mountains (Arnold, 1906; Loel and Corey, 1932; Merriam, 1941) and the Santa Lucia (Loel and Corey, 1932), La Panza (Loel and Corey, 1932), and Caliente Ranges (Eaton, 1939; Repenning and Vedder, 1961) of central California. 


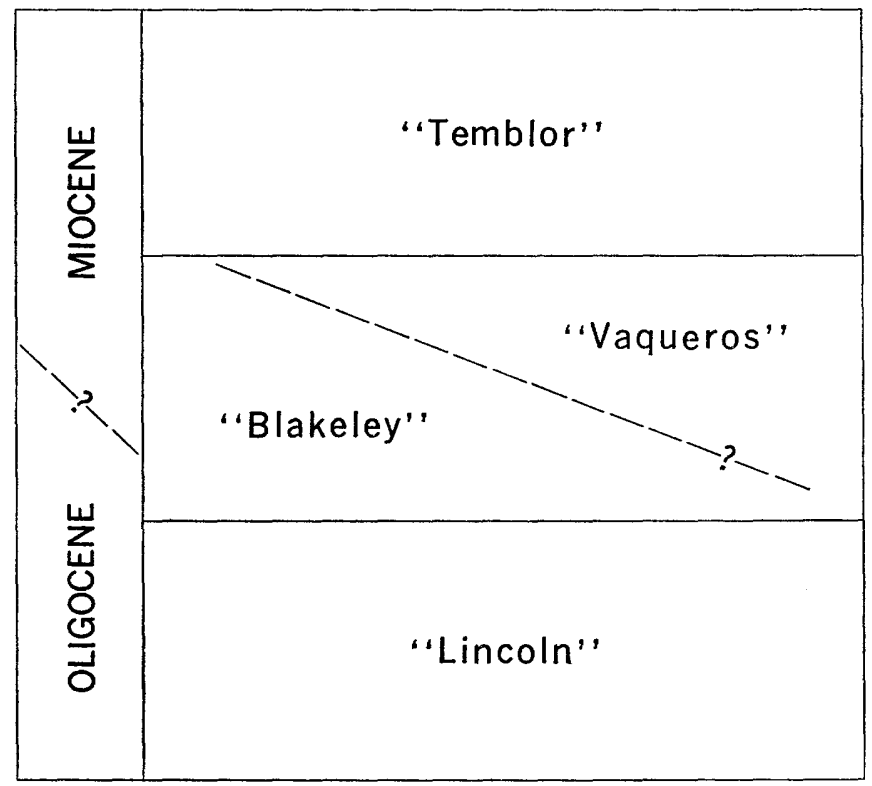

Frgure 3.-Proposed correlation and succession of Oligocene and Miocene Pacific coast megafaunal "stages."

Occurrences east of the San Andreas fault are fewer in number. The northernmost is in the San Benito area of the Diablo Range (lat. $36.5^{\circ} \mathrm{N}$.; Hertlein and others in Wilson, 1943). Other occurrences east of the fault are in the northern part of the Temblor Range (Arnold, 1909), in well cores of the Vedder Sand east of Bakersfield (Corey in Cushman and Laiming, 1931), and near Cajon Pass (Woodring, 1942). A record of $T$. inezana from Douglas County, Oreg. (Dall in Washburne, 1914), seems doubtful because the locality (USGS 5450) is in the type section of the middle Eocene Tyee Formation.

The taxon in the northernmost "Vaqueros" assemblages west of the fault (Santa Cruz Mountains and Point Arena area) is Turritella inezana forma hoffmanni Gabb, a form with subdued spiral sculpture that lacks the characteristic sutural disjunction of $T$ '. inezana s.s. This form also occurs in the northern Temblor Range localities east of the fault.

The northern limit of Turritella inezrna east of the fault is controlled by the large well-known fauna of the San Ramon Sandstone near Walnut Creek (Clark, 1918; Weaver, 1953) and in western Napa County at lat $37.8^{\circ}-38.4^{\circ} \mathrm{N}$. (Weaver, 1949). These strata are referable to the upper part of the "Blakeley Stage" which has been shown to be equivalent, at least in part, to the "Vaqueros Stage" and, therefore, to the biozone of $T$. inezana. They contain a Turritella referable to a middle Tertiary lineage ( $T$. porterensis- $T$. oregonensis) of temperate aspect that has not been found in the warm-water Oligocene to Miocene assemblages.

\section{OTHER WARM-WATER TAXA}

The northernmost "Vaqueros" faunal assemblage on the west side of the fault (Addicott, 1967) is meager and incompletely known because of extremely poor conditions of preservation. "Vaqueros" assemblages in the Diablo and Temblor Ranges east of the fault also are quite small. Because of the sparsity of these critical assemblages and the wide spacing of localities in the northern part of California, it is difficult to find additional warm-water taxa with which the distribution of T. inezana. can be compared.

The distributions of two subtropical to tropical taxa, Lyropecten and Miltha, tend to support the sense of distributional discontinuity shown by Turritella inezana although they do not occur in the northermost exposures of strata referable to the "Vaqueros Stage." The northernmost occurrence of Lyropecten west of the fault is in the Vaqueros Formation of the Santa Cruz Mountains, where it is represented by two species, L. magnolia and L. miguelensis (Arnold, 1906; Loel and Corey, 1932). East of the fault these same species occur in the northern part of the Temblor Range; L. magnotia at USGS Cenozoic locality M2631 near Bitterwater Creek and L. miguelensis at USGS locality M2623 near Franciscan Creek. Nittha, a genus restricted to the Panamic molluscan province of the eastern Pacific Ocean, also has it northernmost occurrence in these two areas.

\section{NORTHERN TAXA EAST OF THE FAULT}

Certain extinct taxa with distributional patterns centered far to the north of California reached the latitude of central California during the middle Tertiary but are restricted to the east side of the San Andreas fault. Perhaps the most distinctive and widespread of these is Mytilus middendorffi, a unique coarsely plicate mussel occurring in strata of early and middle Miocene age. This broadly ranging species occurs from central California northward to the Alaska Peninsula. It is known from localities in the Astoria Formation of Oregon (Durham, 1953; Moore, 1963). All of the California records are from east of the San Andreas fault: Pleasanton area (Hall, 1958), northern Santa Clara County, Standard Univ. loc. 2982), Griswold Hills of southern San Benito County (USGS locs. 5765, 5766), Reef Ridge (Stewart, 1946), and Kern River area (Addicott, 1965).

The extinct northern taxon Miopleiona occurs in "Vaqueros" strata in the Kern River area (Addicott, 1965) and the San Emigdio Range of the southern part of the San Joaquin Valley (Loel and Corey, 1932). It also occurs in the San Ramon Sandstone in the San 


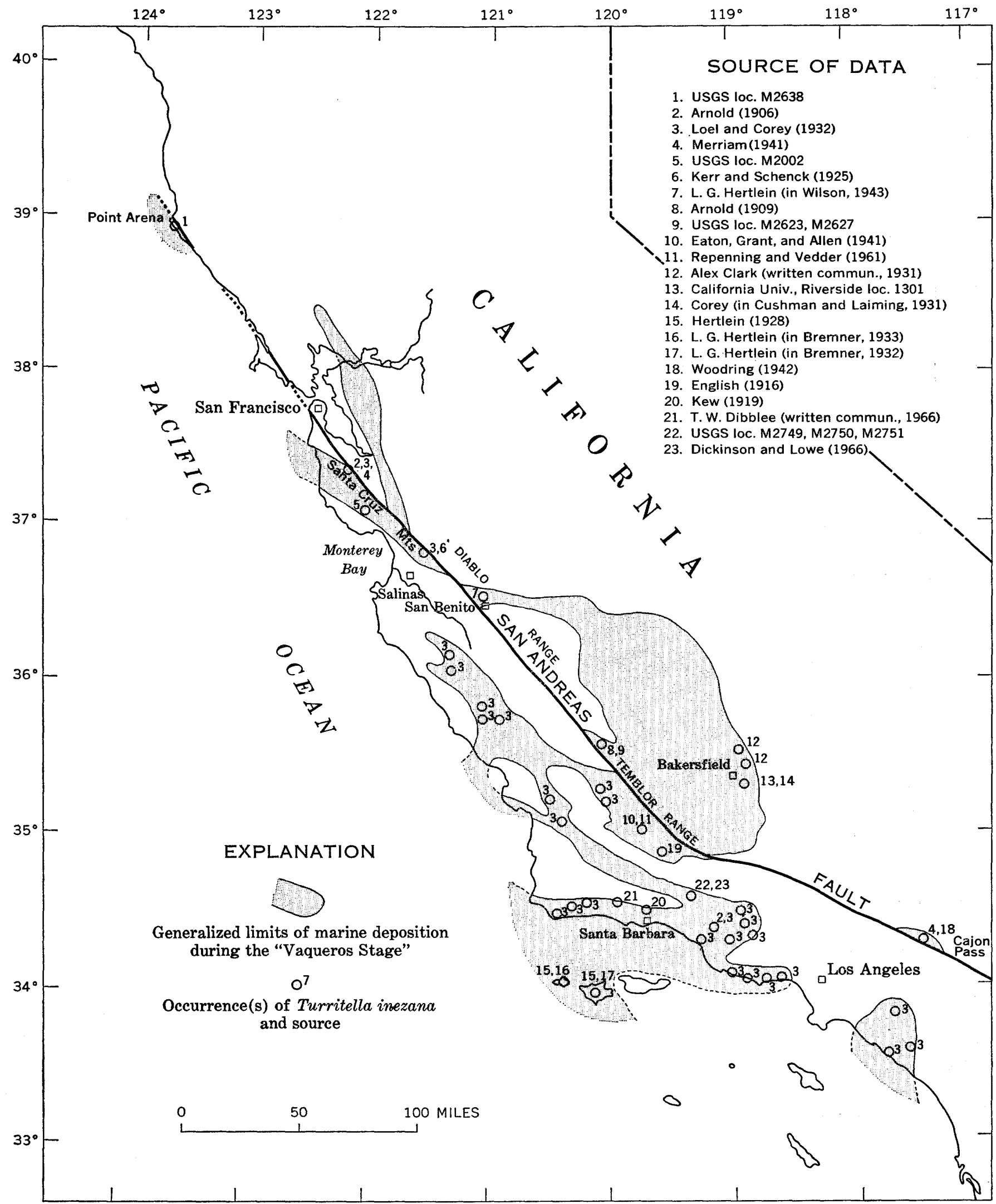

FigURE 4.-Index map of California showing occurrences of Turritella inezana and generalized paleogeography during the "Vaqueros" and "Blakeley Stages." Limits of marine deposition modified, in part, from Corey (1954), Hoots, Bear, and Kleinpell (1945), and Seiden (1964). The embayment east of San Francisco Bay includes strata referable to the "Blakeley Stage" here considered equivalent, in large part, to the "Vaqueros Stage." 
Francisco Bay area far to the north (Clark, 1918). These localities are east of the San Andreas fault, as are those in which Mytilus middendorffi occurs, and there are no early Miocene records of this gastropod from west of the fault.

Still another genus that occurs at many localities in shallow-water early-Miocene deposits east of the fault in the southern part of the San Joaquin Valley but does not occur in coeval strata west of the fault in central California is the gastropod Priscofusus (Addicott, $1965)$. The northern aspect of this extinct genus is indicated by the relative abundance and diversity of species in the lower Miocene Nye Mudstone and middle Miocene Astoria Formation of northwestern Oregon. Its occurrence with Pecten sanctaecruzensis in rocks of Zemorrian age in the Santa Cruz Mountains west of the fault (Burchfiel, 1964) is about 200 miles northwest of the southernmost occurrence in the San Joaquin Valley.

The absence of these distinctive taxa of northerm aspect from "Vaqueros" assemblages of central California west of the fault bolsters the evidence of faunal discontinuity suggested by the distribution of $T$. inezana. However, these northern taxa are much less sensitive indices than shallow warm-water taxa because of the fact that many cool-water forms can extend their normal shallow-water distribution farther southward by inhabiting deeper, and therefore cooler, water, as previously indicated (p. D6).

\section{DISCUSSION}

The occurrence of lower Miocene taxa of warm-water aspect, including the important index species Turritella inezana, much farther northward on the west side of the San Andreas fault than on the east side constitutes an anomalous distributional pattern that seems best explained by large post-early Miocene right-lateral movement. The northern limit of the early Miocene geographic range of $T$. inezana east of the fault is defined by the San Ramon fauna of Contra Costa County. Turritella is present in faunal assemblages from the San Ramon Sandstone, but it is represented by a lineage ( $T$. porterensis- $T$. oregonensis) that, as previously indicated, suggests temperate rather than the subtropical or tropical conditions indicated by the subgenus Torcula (the T. altilira stock of Merriam, 1941), to which $T$. inezana belongs. If it is assumed that the occurrence of this species near Point Arena represents the northernmost limit of its distribution west of the fault and the occurrence in the San Benito area marks the northernmost extent of its distribution east of the fault, the apparent post-early Miocene lateral movement amounts to almost 200 miles. A minimum of about 120 miles of apparent offset is suggested by comparing the Point Arena occurrence west of the fault with the southernmost occurrence of the warm temperate San Ramon fauna in Contra Costa County east of the fault. However, because available data are widely scattered, they permit only generalized estimates.

Lateral movement within the range of 120-200 miles is compatible with the generalized distribution of seaways and marine basins of deposition during the "Vaqueros Stage" depicted in figure 4 and with estimates of 175 miles of right-lateral movement since the early Miocene (Hill and Dibblee, 1953, p. 448-449; Bazeley, 1961). Hill and Dibblee matched interfingering early Miocene marine- nonmarine sequences of the San Emigdio Mountains at the southern end of the San Joaquin Valley and the northern Gabilan Range east of Monterey Bay; Bazeley found what he considered to be identical sets of rock types in pyroclastic units overlying or interfingering with these sequences.

The distance between apparently truncated margins of marine basins in central and southern California shown in figure 4 seems especially significant. The corresponding areas are: (1) strata referable to the "Vaqueros Stage" near Cajon Pass, northeast of the fault, with the Caliente Range-Carrizo Plains area of eastern San Luis Obispo County west of the fault, and (2) the Temblor Range along the southwestern side of the San Joaquin Valley with the Santa Cruz Mountains (fig. 4 ). Although the molluscan assemblages of early Miocene age in the Temblor Range are poorly known, there are many species in common with the Santa Cruz Mountain assemblages listed by Loel and Corey (1932): Bruclarkia barkeriana, Turritella inezana forma hoffmanni, Dosinia margaritana projecta, Lyropecten magnolia, L. miguelensis, Miltha sanctaecrucis, Mytilus expansus, Ostrea vaquerosensis, and Vertipecten nevadanus forma perrini.

These two inferred paleogeographic matches suggest apparent lateral separation of about 150 miles. Early Miocene paleogeography north of the Temblor Range on the east side of the fault and the Santa Cruz Mountains on the west side is poorly controlled. Strata near Point Arena presumably would match the marine embayments intersecting the fault in the area east of Monterey Bay.

If significant lateral movement along the San Andreas fault has not occurred since the early Miocene, the distribution of Turritella inezana would be unusual in the context of the modern shallow-water temperature regime off the California-Baja California coast. If the small warm-water assemblage of the Point Arena area represents an early Miocene open-coast environment, as suggested by the abundance of phosphatic nod- 
ules in the Skooner Gulch Formation and the regional geologic setting, its occurrence far to the north of the inferred protected environment of the San Ramon Sandstone (see fig. 4) is most unexpected because of the tendency for modern open-coast assemblages to be of a clearly cooler aspect than faunal assemblages inhabiting protected bays at similar latitudes. Modern protected environments often contain warm-water species isolated from outer coastal populations farther south. Perhaps the best modern-day example of this distributional discontinuity occurs along the southern coast of Pacific Baja California where mollusks that are otherwise restricted to the tropical Panamic province occur in protected embayments and warm-temperate species occur along the adjacent outer coast (Emerson, 1956, p. 392). Along much of the Baja California and California coast this condition is in part due to seasonal upwelling (California Coop. Oceanic Fisheries Inv., 1953; Bolin and Abbott, 1963) which depresses normal summer temperatures in much of the coastal area. Consequently, protected bays and estuaries have a much greater range of temperatures including higher maxima than do outer coast areas. Although the evidence at hand does not seem to suggest this kind of distribution in late Oligocene and early Miocene time in California, there are indications that temperatures in the southern part of the San Joaquin basin may have been somewhat warmer in central California coastal areas during the late Miocene (Addicott and Vedder, 1963).

The distributional discontinuity of Turritella inezana and some related elements of the "Vaqueros" fauna in central and northern California tend to support earlier contentions of large post-early Miocene rightlateral movement on the San Andreas fault (Hill and Dibblee, 1953; Bazeley, 1961; Dibblee, 1966). By itself the zoogeographic evidence is a somewhat speculative indication of possible dislocation along the fault. Together with the paleogeographic evidence presented herein, Hill and Dibblee's evidence of displaced early Miocene shorelines (1953); and Bazeley's evidence of apparently offset early Miocene volcanic rocks, the faunal discontinuities provide a stronger argument for large lateral movement. These findings should be evaluated and supplemented by additional distributional studies of critical warm-water and cool-water Oligocene and Miocene taxa and studies such as Hall's interpretation $(1960 ; 1962)$ of late Miocene paleotemperatures along the San Andreas fault.

\section{REFERENCES}

Addicott, W. O., 1965, Miocene macrofossils of the southeastern San Joaquin Valley, California, in Geological Survey research 1965 : U.S. Geol. Survey Prof. Paper 52.5-C, p. C101C109, 4 figs.
Addicott, W. O., 1967, Age of the Skooner Gulch Formation, Mendocino County, California: U.S. Geol. Survey Bull. 1254-C. (In press.)

Addicott, W. O., and Vedder, J. G., 1963, Paleotemperature inferences from late Miocene mollusks in the San Luis ObispoBakersfield area, California, in Short papers in geology and hydrology: U.S. Geol. Survey Prof. Paper 475-C, p. C63-C68.

American Commission of Stratigraphic Nomenclature, 1961, Code of stratigraphic nomenclature: Am. Assoc. Petroleum Geologists Bull., v. 45, no. 5, p. 645-665.

Arnold, Ralph, 1906, The Tertiary and Quaternary pectens of California : U.S. Geol. Survey Prof. Paper 47, 264 p., 53 pls. 1909, Paleontology of the Coalinga district, Fresno and Kings Counties, California: U.S. Geol. Survey Bull. 396, 173 p., 30 pls.

Arnold, Ralph, and Hannibal, Harold, 1913, The marine Tertiary stratigraphy of the north Pacific Coast of America: Am. Philos. Soc. Proc., v. 52, no. 212, p. 559-605.

Bandy, O. L., 1958, Dominant molluscan faunas of the San Pedro Basin, California : Jour. Paleontology, v. 32, no. 4, p. 703714.

Bandy, O. L., and Kolpack, R. L., 1963, Foraminiferal and sedimentological trends in the Tertiary section of Tecolote Tunnel, California: Micropaleontology, v. 9, no. 2, p. 117170.

Bazeley, W. J., 1961, 175 miles of lateral movement on the San Andreas fault since lower Miocene? : Pacific Petroleum Geologist Newsletter, v. 15, no. 5, p. 2-3.

Beck, R. S., 1952, Correlation chart of Oligocene, Miocene, Pliocene, and Pleistocene in San Joaquin Valley and Cuyama Valley areas, in Field trip routes, geology, oil fields : Am. Assoc. Petroleum Geologists-Soc. Econ. Paleontologists and Mineralogists-Soc. Explor. Geophysicists Guidebook, Joint Ann. Mtg., Los Angeles, Calif., 1952, p. 104.

Bentson, Herdis, 1940, A systematic study of the fossil gastropod Exilia: California Univ. Pubs., Dept. Geol. Sci. Bull., v. 25, no. 5, p. 199-238, pls. 1-3.

Bolin, R. L., and Abbott. D. P., 1963, Studies on the marine climate and phytoplankton of the central coastal area of California, 1954-1960: California [Marine Research Comm.] Coop. Oceanic Fisheries Inv. Repts., v. 9, p. 23-45.

Bremner, C. St. J., 1932, Geology of Santa Cruz Island, Santa Barbara County, California : Santa Barbara Mus. Nat. History Occasional Paper 1, 33 p., 5 pls.

—_ 1933, Geology of San Miguel Island, Santa Barbara County, California: Santa Barbara Mus. Nat. History Occasional Paper 2, 23 p., 4 pls.

Brown, R. D., Jr., and Gower, H. D., 1958, Twin River Formation (redefinition), northern Olympic Peninsula, Washington: Am. Assoc. Petroleum Geologists Bull., v. 42, no. 10, p. 2492-2512.

Burchfiel, B. C., 1964, Stratigraphic reassignment of four species in the lower Miocene rocks of the Bear Creek area, Santa Cruz County, California: Jour. Paleontology, v. 38, no. 2, p. 401-405.

California Cooperative Oceanic Fisheries Investigations, 1953, Progress report, $1 \mathrm{July} 1952$ to 30 June 1953: $44 \mathrm{p}$.

Clark, B. L., 1918, The San Lorenzo series of middle California : California Univ. Pubs., Dept. Geology Bull., v. 11, no. 2, p. 45-234, pls. 3-24.

-1943 , Notes on California Tertiary correlation : California Div. Mines Bull. 118, p. 187-191. 
Clark, B. L., and Arnold, Ralph, 1923, Fauna of the Sooke Formation, Vancouver Island, with description of a new coral by T. Wayland Vaughan: California Univ. Pubs., Dept. Geol. Sci. Bull., v. 14, no. 5, p. 123-234, pls. 15-42.

Corey, W. H., 1954, Tertiary basins of southern California, [pt.] 8 in chap. 3 of Jahns, R. H., ed., Geology of southern California: California Div. Mines Bull. 170, p. 73-83.

Crouch, R. W., 1952, Significance of temperature on Foraminifera from deep basins off southern California coast: Am. Assoc. Petroleum Geologists Bull., v. 36, no. 5, p. 807-843.

Cushman, J. A., and Laiming, Boris, 1931, Miocene Foraminifera from Los Sauces Creek, Ventura County, California: Jour. Paleontology, v. 5, no. 2, p. 79-120.

Dibblee, T. W., Jr., 1966, Evidence for cumulative offset on the San Andreas fault in central and northern California, in Bailey, E. H., ed., Geology of northern California: California, Div. Mines Bull. 190, p. 375-384.

Dickinson, W. R., and Lowe, D. R., 1966, Stratigraphic relations of phosphate- and gypsum-bearing upper Miocene strata, upper Sespe Creek, Ventura County, California : Am. Assoc. Petroleum Geologists Bull., v. 50, no. 11, p. 2464-2470.

Durham, J. W., 1942, Eocene and Oligocene coral faunas of Washington: Jour. Paleontology, v. 16, no. 1, p. \$1-104, pls. 15-17.

-1944 , Megafaunal zones of the Oligocene of northwestern Washington: California Univ. Pubs., Dept. Geol. Sci. Bull., v. 27, no. 5, p. 101-212, pls. 13-18.

1950, Cenozoic marine climates of the Pacific Coast: Geol. Soc. America Bull., v. 61, no. 11, p. 1243-1264.

1953, Miocene at Cape Blanco, Oregon: Geol. Soc. America Bull., v. 64, no. 12, p. 1817.

1954, The marine Cenozoic of southern California, [pt.] 4 in chap. 3 of Jahns, R. H., ed., Geology of southern California : California Div. Mines Bull. 170, p. 23-31.

Durham, J. W., Harper, Herbert, and Wilder, Beverly, 1942, Lower Miocene in the Willamette Valley, Oregon [abs.]: Geol. Soc. America Bull., v. 53, no. 12, pt. 2, p. 1817.

Eames, F. E., Banner, F. T., Blow, W. H., and Clarke, W. J., 1962, Fundamentals of mid-Tertiary stratigraphical correlation; with a contribution by L. R. Cox; New York, Cambridge Univ. Press, $163 \mathrm{p}$.

Eaton, J. F., 1939, Geology and oil possibilities of Caliente Range, Cuyama Valley, and Carrizo Plain, California : California Jour. Mines and Geology, v. 35, p. 255-274.

Eaton, J. E., Grant, U.S., and Allen, H. B., 1941, Miocene of Caliente Range and environs, California: Am. Assoc. Petroleum Geologists Bull., v. 25, no. 2, p. 193-262.

Emerson, W. K., 1956, Upwelling and associated marine life along Pacific Baja California, Mexico: Jour. Paleontology, v. 30, no. 2, p. 393-397.

English, W. A., 1916, Geology and oil prospects of Cuyama Valley, California: U.S. Geol. Survey Bull. 621-M, p. 191-215.

Etherington, T. J., 1931, Stratigraphy and fauna of the Astoria Miocene of southwest Washington : California Univ. Pubs., Dept. Geol. Sci. Bull., v. 20, no. 5. p. 31-142, 14 pls.

Gower, H. D., 1960, Geologic map of the Pysht quadrangle, Washington: US. Geol. Survey Geol. Quad. Map GQ-129, scale $1: 62,500$.

Hall, C. A., Jr., 1958, Geology and paleontology of the Pleasanton area, Alameda, and Contra Costa Counties, California : California Univ. Pubs. Geol. Sci., v. 34, no. 1, p. 1-90, 12 pls.
Hall, C. A., Jr., 1960, Displaced Miocene molluscan provinces along the San Andreas fault, California: California Univ. Pubs. Geol. Sci., v. 34, no. 6, p. 281-308.

1962, Reply [to critical review by J. W. Durham and S. R. Primmer of "Displaced Miocene molluscan provinces along the San Andreas fault, California" (1960)]: Am. Assoc. Petroleum Geologists, v, 46, no. 10, p. 1953-1960.

1964, Shallow-water marine climates and molluscan provinces: Ecology, v. 45, no. 2, p. 226-234.

Ham, C. K., 1952, Geology of Las Trampas Ridge, Berkeley Hills, California: California Div. Mines Spec. Rept. 22, $26 \mathrm{p}$.

Hertlein, L. G., 1928, Preliminary report on the paleontology of the Channel Islands, California: Jour. Paleontology v. 2 , no. 2, p. 142-157, 4 pls.

Hill, M. L., and Dibblee, T, W., Jr., 1953, San Andreas, Garlock, and Big Pine faults, California-a study of the character, history, and tectonic significance of their displacements: Geol. Soc. America Bull., v. 64, no. 4, p. $443-458$.

Hoots, H. W., Bear, T. L., and Kleinpell, W. D., 1954, Geological summary of the San Joaquin Valley, Califormia, [pt.] 8 in chap. 2 of Jahns, R. H., ed., Geology of southern California : California Div. Mines Bull. 170, p. 113-129.

Jones, G. F., 1964, The distribution and abundance of subtidal benthic Mollusea on the mainland shelf of southern CaIifornia : Malacologia, v. 2, no. 1, p. 43-68.

Kerr, P. F., and Schenck, H. G., 1925, Active thrust faults in San Benito County, California: Geol. Soc. America Bull., v. 36 , no. 3 , p. $465-494$.

Kew, W. S. W., 1919, Geology of a part of the Santa Ynez River district, Santa Barbara County, California: California Univ. Pubs., Dept. Geology Bull., v. 12, no. 1, p. 1-21, 2 pls.

Kleinpell, R. M., 1938, Miocene stratigraphy of California: Tulsa, Okla., Am. Assoc. Petroleum Geologists, 450 p.

Kleinpell, R. M., and Weaver, D. W., 1963, Oligocene biostratigraphy of the Santa Barbara embayment, California: California Univ. Pubs. Geol. Sci., v. 43, 250 p., 38 pls.

Lipps, J. H., 1965, Oligocene in California?: Nature, v. 208, no. 5013, p. 885-886.

Ioel, Wayne, and Corey, W. H., 1932, The Vaqueros formation, Lower Miocene of California; [pt.] 1, Paleontology: California Univ. Pubs., Dept. Geol. Sci. Bull., v. 22, no. 3, p. $31-410$, pls. $4-65$.

Lutz, G. C., 1951, The Sobrante sandstone: California Univ. Pubs., Dept. Geol. Sci. Bull., v. 28, no. 13, p. 367-406, pls. 15-18.

Merriam, C. W., 1941, Fossil Turritellas from the Pacific Coast region of North America: California Univ. Pubs., Dept. Geol. Sci. Bull., v. 26, no. 1, p. 1-214, pls. 1-214, 19 figs.

Moore, E. J., 1963, Miocene marine mollusks from the Astoria Formation in Oregon: U.S. Geol. Survey Prof. Paper 419, 109 p., 30 pls.

Newell, I. M., 1948, Marine molluscan provinces of western North America-A critique and a new analysis: Am. Philos. Soc., v. 92 , no. 3, p. 155-166.

Pease, M. H., Jr., 1954, Geology of the Sobrante anticline and vicinity, Briones Valley quadrangle, Contra Costa County, California: Berkeley, California Univ., M.A. thesis.

Peck, D. L., Griggs, A. B., Schlicker, H. G., Wells, F. G., and Dole, H. M., 1964, Geology of the central and northern parts of the western Cascade Range in Oregon: U.S. Geol. Survey Prof. Paper 449, 56 p. 
Primmer, S. R., 1964, Preliminary report on the type Kirker Formation, in Guidebook to the Mount Diablo field trip, 1964: Davis, Calif., Geol. Soc. Sacramento, p. 60-69.

Repenning, C. A., and Vedder, J. G., 1961, Continental vertebrates and their stratigraphic correlation with marine mollusks, eastern Caliente Range, California, in Short papers in the geologic and hydrologic sciences: U.S. Geol. Survey Prof. Paper 424-C, p. C235-C239.

Rothwell, W. T., Jr. 1965, Regional correlation of Pacific Coast Oligocene microfaunas: Am. Assoc. Petroleum Geologists Bull., v. 49, no. 10, p. 1766.

Schenck, H. G., 1936, Nuculid bivalves of the genus Acila: Geol. Soc. America Spec. Paper 4, 149 p., 18 pls.

Seiden, Hy, 1964, Kettleman Hills area [California]: San Joaquin Geol. Soc. Selected Papers, v. 2, p. 46-53.

Smith, J. P., 1919, Climatic relations of the Tertiary and Quaternary faunas of the California region: California Acad. Sci. Proc., 4th ser., v. 9, no. 4, p. 123-173.

Stewart, Ralph, 1946, Geology of Reef Ridge, Coalinga district, California : U.S. Geol. Survey Prof. Paper 205-C, p. 81-115, pls. 9-17.

Tegland, N. M., 1933, The fauna of the type Blakeley upper Oligocene of Washington: California Univ. Pubs., Dept. Geol. Sci. Bull., v. 23, no. 3, p. 81-174, pls. 2-15.

Valentine, J. W., 1961, Paleoecologic molluscan geography of the Californian Pleistocene: California Univ., Dept. Geol. Sci. Bull., v. 34, no. 7, p. 309-442.

1963, Biogeographic units as biostratigraphic units : Am. Assoc. Petroleum Geologists Bull., v. 47, no. 3, p. 457-466.

Vaughan, T. W., and Wells, J. W., 1943, Revision of the suborders, families, and genera of the Scleractinia: Geol. Soc. America Spec. Paper 44, 363 p., 51 pls.
Wagner, C. M., and Schilling, K. H., 1923, The San Lorenzo Group of the San Emigdio region, California: California Univ. Pubs., Dept. Geol. Sci. Bull., v. 14, no. 6, p. 235-276, pls. 43-50.

Washburne, C. W., 1914, Reconnaissance of the geology and oil prospects of northwestern Oregon: U.S. Geol. Survey Bull. $590,111 \mathrm{p}$.

Weaver, C. E., 1916, The Tertiary formations of western Washington: Washington Geol. Survey Bull. 13, 327 p.

1937, Tertiary stratigraphy of western Washington and northwestern Oregon: Washington Univ. Pub. Geology, v. 4, 266 p.

1944, Geology of the Cretaceous (Gualala Group) and Tertiary formations along the Pacific Coast between Point Arena and Fort Ross, California: Washington Univ. Pub. Geology, v. 6, no. 1, p. 1-29.

1949, Geology of the Coast Ranges immediately north of the San Francisco Bay region, California : Geol. Soc. America Mem. 35, 242 p.

- 1953, Eocene and Paleocene deposits at Martinez, California: Washington Univ. Pub. Geology, v. 7, 102 p.

Weaver, C. E., and others, 1944, Correlation of the marine Cenozoic formations of western North America: Geol. Soc. America Bull., v. 55, no. 5, p. 569-598.

Wells, J. W., 1957, Coral reefs, chap. 20 of Hedgpeth, J. W., ed., Treatise on marine ecology and paleoecology: Geol. Soc. America Mem. 67, v. 1, Ecology, p. 609-631.

Wilson, I. F., 1943, Geology of the San Benito quadrangle, California: California Jour. Mines and Geology, v. 39, no. 2, p. 183-270.

Woodring, W. P., 1942, Marine Miocene mollusks from Cajon Pass, California : Jour. Paleontology, v. 16, no. 1, p. 78-83. pls. 13, 14 . 


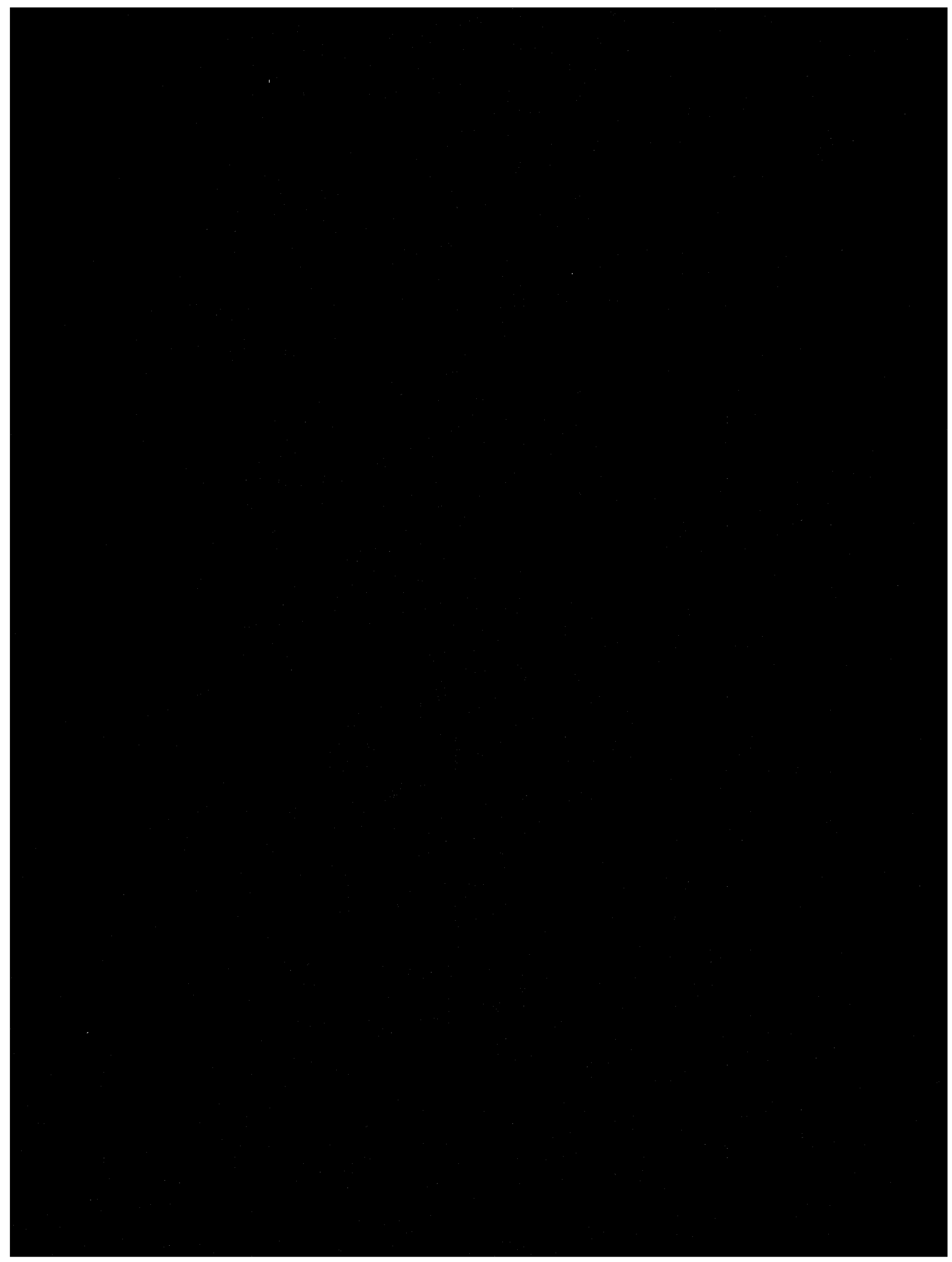




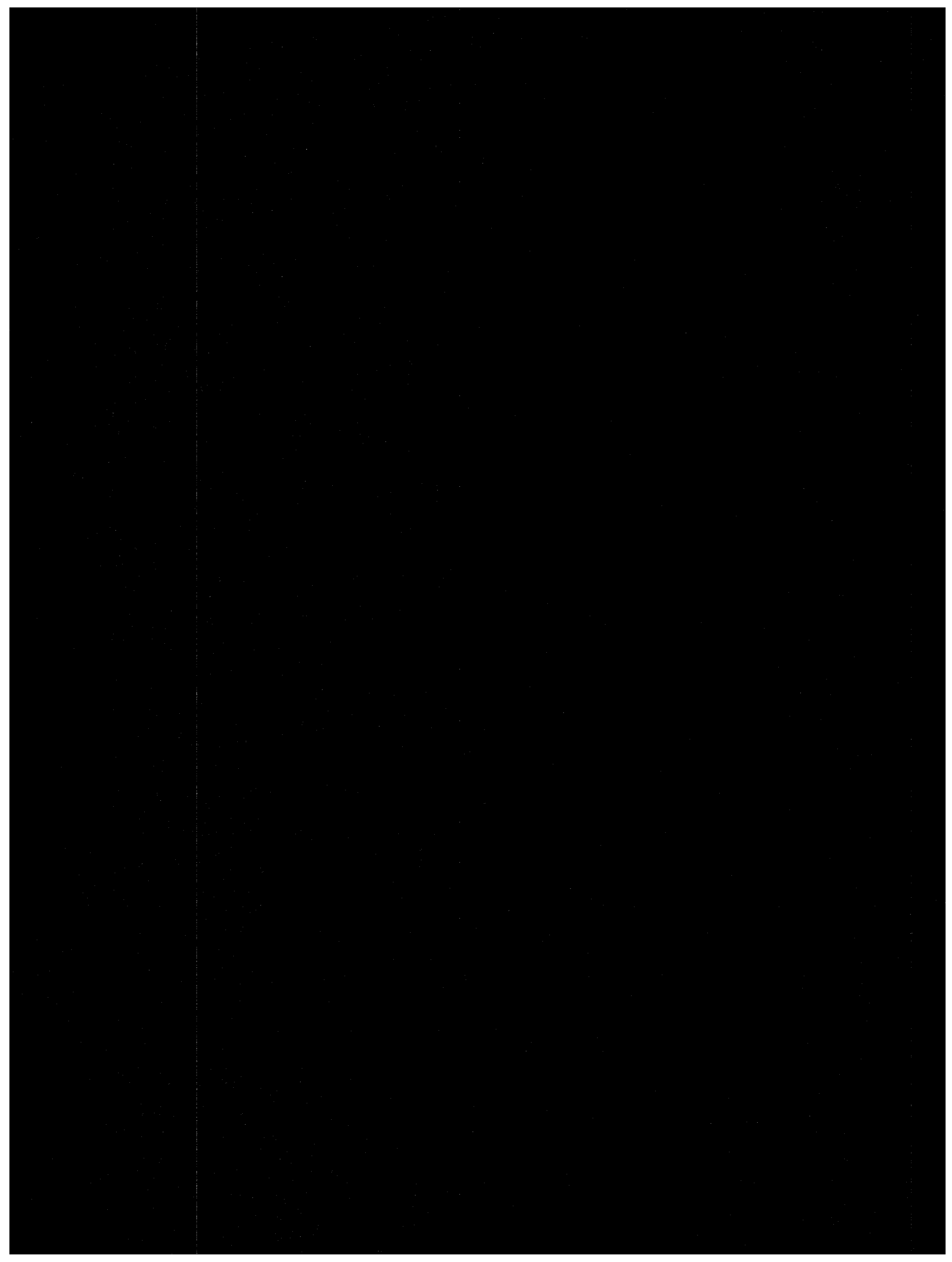

